\title{
Equatorial
}

\section{Contos de assombração e catolicismo popular: aspectos da vivência religiosa em uma comunidade mineira}

\author{
Marcelo Elias Bernardes \\ Mestrando em Ciências Sociais \\ Universidade Estadual Paulista "Júlio de Mesquita Filho" \\ marcelocsunesp@yahoo.com.br
}

\section{RESUMO}

Este artigo procura discutir as bases e as dimensões de uma prática tradicional no município mineiro de Caldas, contar narrativas de assombração, não unicamente como um estrato da cultura popular local, mas colocando em perspectiva uma religiosidade popular de caráter híbrido. Imersos na tradição oral e na memória coletiva, a mobilidade das ideias e o imaginário contidos nos contos possibilitaram que esse sistema de crenças se encontre presente na cotidianidade local e dialogue com outras práticas culturais e formas de pensamento, que se tornaram acessíveis à população por meio dos aparatos de comunicação eletrônica. Nesse sentido, a metodologia da história oral e a coleta de dados etnográficos nos permitiu adentrar a este universo mental e investigar a relação da população com as assombrações.

Palavras-chave: Tradição; Antropologia da Religião; Práticas Religiosas; Imaginário; Globalização.

\section{Introdução}

O município de Caldas, localizado no sul de Minas Gerais, possui historicamente em diversos aspectos de sua formação, a mão condutora do catolicismo. Esta colocação pode ser ilustrada ao considerarmos que muitos espaços públicos são patrimônios pertencentes à Igreja Católica. Na praça central da cidade encontram-se, em suas extremidades, duas igrejas, Matriz e Rosário, além da casa e do salão paroquiais e algumas residências onde são ministradas as aulas de catequese e crisma, todas situadas em seu centro histórico.

Observamos ainda que todos os bairros rurais que conhecemos possuem sua própria capela construída em muitas ocasiões ao lado do centro comunitário. Nesse sentido, os nomes de algumas localidades ao fazerem referência aos 
santos católicos, como as comunidades rurais de São Pedro de Caldas, Santo Antônio e Santana, revelam a devoção da população local e a preferência por um santo, que é considerado padroeiro (AZZI, 1978). Desta forma, para compreendermos a importância que a religiosidade possui no cotidiano dos moradores locais, nos parece relevante colocar em perspectiva um conceito de lugar mais amplo, entendendo que ele faz parte do processo de fornecimento de sentido às relações sociais através do tempo a partir de uma relação mútua que envolve pessoas, lugares e histórias e instituições (TRAJANO FILHO, 2010). Existem ainda bairros urbanos que possuem nomes ligados à cosmovisão católica como Nossa Senhora das Graças, popularmente chamado de Casinhas e Santa Cruz, ambos localizados de forma marginal na cidade.

Quanto às casas da população que tivemos oportunidade de visitar encontramos ornamentos do universo cosmológico católico, como estatuetas de santos da mesma maneira que crucifixos e quadros sacros e em algumas casas percebemos também a existência de pequenos altares de devoção, com velas acesas e copos de água de benta, que ocupam muitas vezes um cômodo inteiro. Desta forma, entendemos tal como Eliade (1992) que existe uma preocupação dos devotos em fazer de sua residência um locus sagrado. Estas disposições do espaço são capazes de revelar uma forma de compreender uma realidade que perpassa por transformações, mas que permanece ancorada em uma ótica religiosa.

Esta configuração do espaço privado apresenta-se como uma herança colonial, como descreve Luiz Mott sobre o interior das casas " $\mathrm{Na}$ parede da sala de muitas casas coloniais, saindo do quarto, lá estavam para ser venerados e saudosos os quadros ou registros dos santos de maior devoção dos donos da morada, [...]" (1997, p.166). Além do exercício da religiosidade na cotidianidade doméstica, observamos na cidade uma grande quantidade de cerimônias, como missas e terços, novenas e festas de santos distribuídos ao longo do calendário oficial. Estes elementos que fazem parte da esfera pública caldense são essenciais para a vida religiosa dos devotos, mas se configuram também como uma forma de distinção social na comunidade (VALLE, 2007), em uma rede de relações de poder, cujo discurso gravita em torno da devoção.

Outro atributo pertinente ao local desta investigação são os aspectos da ruralidade, presente na vida das pessoas e que também está relacionada com suas 
formas de pensar. Nesse sentido, definimos o mundo rural não apenas como dimensãoespacialemoposiçãoàcidade,comoformadevidaedepensamento(CARNEIRO, 2008), o que nos leva a refletir que esta possível dicotomia, em Caldas, deve ser olhada minuciosamente porque são categorias que se complementam.

Esta observação é nítida também quando nos voltamos para a economia do município, centrada nas atividades rurais, como plantações familiares de café, milho e verduras e na pecuária, com a produção de leite. As fábricas locais, a maioria localizada na cidade e que empregam grande parcela da população, estão voltadas para a manufatura destes produtos rurais. Identificamos que a maioria dos bens produzidos são derivados do leite, como queijos e doces, que são comercializados em várias regiões do Brasil, sobretudo nas regiões nordeste e sudeste. Já os produtos agrícolas são vendidos tanto nas feiras e mercados locais quanto nos ceasas do sudeste.

Nas áreas rurais do município, as plantações que abastecem estes mercados também sustentam as famílias que cultivam estes produtos, em um espaço que é marcado pela associação entre a vida afetiva e o trabalho (BRANDÃO, 2007; MOURA,1988) e que tece um sentimento de pertencimento e identidade com a terra e o modo de vida. Uma grande parte das famílias que moram na cidade também ilustram o vínculo com a terra ao cultivarem em seus quintais, hortas com árvores frutíferas, vegetais e hortaliças, direcionados unicamente ao consumo próprio e que também podem servir como troca entre vizinhos.

A amálgama entre a religiosidade e a vida campesina permitiu que determinados ritos da cultura popular continuassem vivos na contemporaneidade, sobretudo porque o município mantém esta base rural. O gosto pelas modas de viola ilustra a vida caipira cotidiana, que agrega sempre um número significativo de pessoas que se envolvem neste contexto. Os jogos de baralho também emergem como uma prática popular comum em ambientes familiares e públicos. Dentro da configuração dos bairros rurais percebemos ainda a existência de uma venda, que possui múltiplas funcionalidades sociais, servindo como ponto de encontro, onde as pessoas se reúnem após dia de trabalho na terra. Ele também atua como armazém, uma vez que o tamanho do município dificulta o deslocamento para a compra de alimentos que possam faltar cotidianamente. Assim, observamos que a 
vida na zona rural caldense é bastante marcada por dificuldades que emergem cotidianamente, como a falta de médicos, de mercados e, considerando a religiosidade local, de uma vida pública católica mais ativa, uma vez que poucas missas são realizadas anualmente em cada comunidade rural.

Neste contexto que envolve as religiosidades populares, propomos analisar os contos de assombração e a sua proximidade com a população local, em um contexto de produção de sentidos religiosos, uma vez que manifestam a crença em criaturas, espíritos e seres fantásticos que carregam um discurso católico, tecido nas cotidianidades locais, muitas vezes afastadas do centro religioso por ocasião de dificuldades materiais que possibilitariam uma maior constância nestas aproximações. Não obstante, não podemos negligenciar os diálogos e convergências culturais com outras religiosidades, como africanas, indígenas e espíritas, presentes na formação do município e recentemente evangélicas. Considerando que a crença nestas assombrações e a tradição de contar estas narrativas se configuram como elementos de uma identidade coletiva, produzida historicamente, devemos olhá-los a partir de uma perspectiva do dinamismo e da mobilidade. Em nossas jornadas em campo, percebemos que estas características, estão muito presentes na vida cotidiana, o que modificou a relação das novas gerações não unicamente com as narrativas de assombração ou a crença em sua existência, mas com a cultura local de uma forma geral, atribuindo-lhe novos significados.

Todo este aparato cultural e religioso que envolve as assombrações está fundamentado sobre a oralidade popular. Não conseguimos encontrar qualquer tipo de fonte escrita ou impressa, seja em jornais, boletins de ocorrência ou documentos da Santa Casa que pudessem nos fornecer outras visões e perspectivas acerca destes seres fantásticos. Em face disso, optamos por utilizar duas metodologias que privilegiam o contato com os agentes locais: a história oral e o método etnográfico. A história oral nos possibilita o registro de fontes orais, através da realização de entrevistas, e a aproximação com indivíduos que experenciaram acontecimentos, conjunturas e visões de mundo (ALBERTI, 2005). Assim, Verena Alberti (2005) entende que a importância da história oral reside em "[...] compreender a sociedade através do indivíduo que nela viveu [...]” (idem, 2005, p. 19) e cuja peculiaridade “[...] decorre de toda uma postura 
com relação à história e às configurações socioculturais, que previlegiam a recuperação do vivido conforme concebido por quem viveu" (ibidem, 2005, p. 23).

Neste trabalho, utilizamos nove entrevistas, coletadas entre os anos de 2012 e 2017, sendo quatro homens e quatro mulheres de variadas faixas etárias - informadas em cada trecho citado no corpo do texto - o que permitiu refletir sobre a questão geracional e sua relação com nosso objeto, as narrativas de assombração, sobretudo porque o processo da globalização proporcionou modificações nas práticas culturais locais e nos contos de assombração, modificando parcialmente seus sentidos, mas que continuam a engendrar a identidade católica por meio de sua transmissão - a oralidade e a memória. Cabe aqui elucidar algumas condições acerca das coletas das entrevistas e algumas dificuldades enfrentadas durante as incursões à campo.

Primeiramente, a aproximação com alguns moradores, apontados como "contadores de histórias" foi bastante complicada, uma vez que constatamos certa resistência em desenvolver conversas abertas com desconhecidos e muitos até negaram conhecer os "causos de assombração". Em contrapartida, ao longo dos anos, fomos conhecendo mais pessoas, que nos contavam algumas narrativas ou indicavam pessoas que conheciam estas histórias, como foi o caso da entrevista com a senhora S.R.B., hoje com setenta e três anos, na qual seu neto levou-nos até sua residência, localizada no bairro urbano chamado "Olaria".

Outro ponto de grande dificuldade gravita em torno da desconfiança da maioria da população em aceitar a gravação das entrevistas. Muitos rejeitaram-na e concordaram apenas em falar sem a utilização de equipamentos para que escrevessemos os contos. Estes aspectos nos parecem informar sobre uma característica importante da cultura local, a relação de desconfiança com aquilo é desconhecido, mencionado por Antônio Candido (2010) e entendido como uma característica pertencente à cultura rústica.

Atrelado à história oral, ao entendermos que a crença nas assombrações não se restringe à pratica de contar, fazendo parte na vida cotidiana em muitos aspectos, optamos por utilizar a etnografia como perspectiva metodológica que permite uma produção de conhecimentos a partir da coleta de dados em um contexto de contato estreito com a população (MALINOWSKI, 1978). Dessa forma, a observação participante contribuiu para 
compreendermos melhor a complexidade do sistema simbólico local, no qual as representações sobre as assombrações se comportam apenas como uma parte integrante da cultura caldense. Assim, o contato com a cotidianidade local, suas festividades, os eventos religiosos, importantes para a população, que é formada em sua maioria por católicos, e as aproximações às suas formas de pensar, entendidas como experiência próxima por Geertz (1997), foram em grande medida, proporcionadas pelo método etnográfico.

\section{Improvisações e convergências culturais na formação social de Caldas}

Ainda que a presença do catolicismo português seja relevante na formação da comunidade de Caldas, não podemos jogar luz unicamente a ele neste processo, uma vez que ela se constituiu a partir da interação social com a etnia kaiapó e os escravos (PIMENTA, 1998). Os índios kaiapós habitavam a região de Caldas quando foi estabelecido o primeiro arraial em meados do século XVIII e passaram a ser chamados de "bugres" pelos colonos, nome dado a um ribeirão que passa nas margens da cidade e que pode nos fornecer referencias sobre a localização da tribo em termos geográficos. Segundo o memorialista local Reynaldo Pimenta (1998), estes encontros foram marcados por intercâmbios culturais, em que a população local no final do século XIX, esboçava traços característicos kaiapós em suas festas católicas ${ }^{1}$.

Além das convergências culturais explicitadas nas festas, é emblemático pensar a importância de determinados ritos e representações na construção da religiosidade caldense, que fazem parte do cotidiano na contemporaneidade, ainda que se encontrem em processo dinâmico de transformação e que os agentes sociais interpretam-nas segundo seus interesses e subjetividades, atualizando, desta forma, os significados da cultural local (SAHLINS, 1990). Dentre os hábitos de alguns caldenses, identificamos o uso de plantas com uma finalidade de proteção espiritual, como o alecrim e a arruda, cujos significados podem variar entre o combate aos maus olhados, que podem implicar na morte de plantas e animais domésticos ou ligados à pecuária e a prevenção da entrada de espíritos ruins nas residências, capazes de atormentar a vida das famílias.

$\mathrm{Na}$ perspectiva de alguns agentes locais, estes espíritos podem ser considerados assombrações ao possuírem um caráter profano eviden- 
ciado a partir de determinadas interpretações de acontecimentos locais ${ }^{2}$. Estas práticas que engendram benzimentos são capazes de revelar a tecitura de hibridismos religiosos na vida cotidiana contemporânea em localidades rurais e urbanas brasileiras, uma vez que a crença na força de espíritos malignos é um elemento presente em várias religiões, como entre algumas etnias nativas (FREYRE, 2006) e africanas (SWEET, 2007).

A presença escrava desde o estabelecimento das primeiras moradias se configura como outro marco do processo da formação social, religiosa e cultural em Caldas. A região do Sul de Minas foi marcada durante o período colonial por território de passagem entre São Paulo e região aurífera do centro sul do Estado. A ocupação dos colonos na região do Planalto da Pedra Branca ${ }^{3}$ com a intenção de estabelecer fazendas trouxe as primeiras levas de escravos, muitos já nascidos na colônia e batizados pelo catolicismo, mas o que não implicou na perda de suas referências cosmológicas, como bem mostrou James Sweet (2007).

Observamos a existência de um patrimônio material no município, como muros, fossos e bases de casas que resistem ao processo de degradação e que são, em grande medida, desvalorizados pelo poder público local. Outro aspecto de permanência se inscreve nas religiosidades, o que nos fornece um ponto de ancoragem para pensarmos o reconhecimento de seu poder religioso, como a crença nos feitiços e possessões, presentes no município, sobretudo hoje em terreiros de umbanda. Neste ponto, chama-nos atenção também a incorporação de alguns elementos do candomblé, como o sacrifício de animais e que acabam reforçando a autoridade do discurso católico da religiosidade africana enquanto práticas do diabo e reatualizando o imaginário local acerca da aproximação entre estas religiosidades e o pecado (SWEET, 2007).

Pensar nestas terras, que futuramente viriam a ser chamadas de Caldas, após determinação de um alvará régio em 1813, requer considerar alguns fatores essenciais para observarmos a construção coletiva das religiosidades e sua importância na constituição de uma identidade local. Procuramos observar a interação entre variadas cosmologias e práticas construídas historicamente e que permitiram que os contos populares sobre as assombrações fossem gradativamente incorporados à vida cotidiana e a identidade coletiva.

Para compreendermos melhor este processo de hibridismo cultural em 
Caldas, presente na contemporaneidade, tomamos como fundamento analítico a perspectiva dada por Luis Mott (1997) às dificuldades que o catolicismo português encontrou em sua colônia para que suas práticas públicas se cristalizassem da mesma forma como no Velho Mundo ${ }^{4}$. Neste aspecto, a extensão territorial, a pouca urbanização, o número insuficiente de padres e os perigos do transporte interno foram apontados como mecanismos decisivos para a constituição de ritos e celebrações religiosas no contexto doméstico e privado.

Aqui, muitos e muitos dos moradores passavam anos sem ver um sacerdote, sem participar dos rituais nos templos ou freqüentar os sacramentos. Tal carência estrutural levou de um lado à maior indiferença e apatia de nossos antepassados ante as práticas religiosas comunitárias, do outro, ao incremento da vida religiosa privada, que na falta do controle dos párocos, abria maior espaço para desvios e heterodoxias (MOTT, 1997, p. 163).

Ao observamos Caldas a partir destas perspectivas e considerando, sobretudo a enormidade de sua extensão territorial, muito maior na época colonial, vislumbramos um campo em aberto para as convergências culturais e religiosas, fértil para a criatividade, o trânsito e a emergência de práticas comungadas que reiteram a confecção de um imaginário em movimento. Desta maneira, séculos atrás, o relativo isolamento de famílias do centro religioso e político, que permanece no mesmo local, a praça central da cidade, e a dificuldade de locomoção, contribuíram para a improvisação de ritos de batismo, casamento, morte, medicinais, entre outros, procurando, portanto, resolver questões concretas do cotidiano (MELLO e SOUZA, 1986).

Estas práticas de improviso também se estenderam às formas de obtenção da alimentação e da construção das moradias, como bem elucidou Antonio Cândido (2010) e não podem ser pensadas fora da esfera do hibridismo, uma vez que haviam escravos nas fazendas ou mesmo alforriados e fugidos além das relações com indígenas, cujas variadas formas de religiosidade e práticas se convergiram diante das necessidades do cotidiano.

Foi nesses espaços novos, nesse mundo distinto que homens cada vez mais familiarizados com hábitos de privacidade improvisaram, à sua moda, novas formas de vivê-los - inclusive para poderem suportar melhor o imprevisto de situações inéditas e neutralizar a angústia ante seus desdobramentos (MELLO e SOUZA, 1997, p. 44).

A partir destas trocas, intercâmbios e conflitos, a população desta re- 
gião, ao se criar nas interações e na mobilidade, foi tecendo uma identidade coletiva e fluída que desembocou em um mútuo reconhecimento em um processo no qual as diversas formas de comunicação e discursos propiciaram uma constante produção de sentidos tanto no que cerca a vida material quanto ao imaginário (ORLANDI, 2015). Contudo, não podemos observar a montagem deste panorama sem elucidar a noção de que o processo de colonização carrega marcas de imposição cultural e exploração do trabalho, sobretudo porque sua sociedade foi fundamentada em uma estratificação polarizada, entre senhores e escravos e dominadores e dominados, e nas zonas intermediárias emergiram variadas formas e espaços de aproximação, mas que não deixam de explicitar as marcas da dominação (NOVAIS, 1997).

\section{Narrativas de assombração como expressões do catolicismo popular}

Os contos populares de assombração estão inseridos neste processo, sobretudo porque historicamente não se apresentaram como simples narrativas para grande parte população de Caldas, ainda que as formas como são apropriados pelos agentes pode apresentar variações. Eles trazem em seu bojo a marca de religiosidades tecidas nas rotinas e em hábitos diários por séculos e que foram ganhando suas especifidades ao longo do tempo. Neste aspecto, não nos cabe concebê-los como uma prática sui generis que se desenvolveu na região, pelo contrário, ao inserirmos estes "causos" ${ }^{5}$ dentro de uma cultura gestada no período colonial, entendemos que tais narrativas fazem parte de uma rede de mobilidades, muito marcada pela circularidade das ideias e que se torna lúcida ao considerarmos a transitoriedade na colônia como uma característica inerente ao seu funcionamento (NOVAIS, 1997) ${ }^{6}$.

A interconexão entre o mundo dos vivos e dos mortos, que verificamos em alguns contos caldenses, nos quais almas penadas se comunicam com os seres humanos, parece-nos uma herança portuguesa e européia marcada pelo medo e que desembarcou na América Portuguesa convergindo-se com as representações das etnias nativas e africanas (MELLO e SOUZA, 1986). Nesse sentido, no imaginário medieval europeu, a morte não era concebida como um movimento de ruptura com o mundo dos vivos, mas como uma continuidade vivenciada diariamente (DUBY, 2003). 
Ao colocarmos em perspectiva as narrativas de assombração, encontramos elementos que permitem pensar esta relação como uma permanência, mas que perpassou por processos de tradução cultural e transformações ao longo dos séculos, como observamos em um conto recente que R. E. N. nos forneceu, sobre uma mulher que faleceu e começou a aparecer, algumas semanas depois, em sua antiga casa ${ }^{7}$.

Dizem que a "Lurdes" está aparecendo ali na casa dela. Ela apareceu para a moça que está morando lá agora. Acho que se chama "Vanuza", trabalhava no Boticário. Ela é uma ótima pessoa assim sabe. A moça contou que viu ela semana passada dentro da casa [...] ela não quer ficar mais lá. "Eu rezo, faço minhas preces em nome do senhor Jesus. Quem estiver perturbando aqui que vá para outro lugar (R.E.N., entrevista, 06/01/2017, 54 anos, Caldas).

Esta narrativa nos elucida acerca das aproximações entre a concepção local de alma penada, que carrega consigo uma variabilidade interna, e as assombrações, comuns no catolicismo popular, uma vez que estas representações ao serem entendidas pelo clero como superstições, extrapolam os limites do catolicismo oficial (VILHENA, 2004). Durante nossa vivência na comunidade, nos defrontamos com diversas possibilidades interpretativas que procuram explicar as aparições das almas penadas, como sofrimento, dor, pecado e apego à materialidade na vida terrena, sendo esta última uma convergência com o espiritismo, o que nos reforça a ideia de proximidade com o catolicismo popular e o dinamismo de um hibridismo cultural e religioso que não se encontra de forma estagnada.

Dentro destas possibilidades e considerando que "Lurdes" foi uma pessoa querida na cidade, observada como trabalhadora e pessoa honesta, valores socias importantes em Caldas, e veio a falecer relativamente nova por motivo de doença, é possível pensar que a interpretação feita por "Vanuza", a partir dos significados deste imaginário coletivo, entenda que as frequentes aparições de "Lurdes" estejam atreladas ao sofrimento e dor durante seu adoecimento. Outra alternativa de interpretação pode ser o seu apego às coisas materiais que faziam parte de sua cotidianidade, o que apontaria a permanência de sua alma na casa. Entretanto, tal como Sahlins (1990) discute, considerando "Vanuza" enquanto uma agente social que possui interesses próprios, não podemos descartar a possibilidade da utilização de determinados significados culturais locais, para abandonar uma propriedade alugada ou facilitar uma rescisão con- 
tratual, uma vez que a casa assombrada pertence à família da mulher morta.

Neste conto, nossa narradora procura parafrasear "Vanuza", de quem ela ouvira a história, uma performance muito comum na estrutura da arte de narrar, e que mostra-nos, neste contexto, a interação entre estas narrativas e uma crença construída na cotidianidade local. No discurso de R.E.N., católica praticante, identificamos elementos do universo cristão, capazes de nos mostrar que a religiosidade se comporta como uma forma de interpretação da realidade (GEERTZ, 1989). Neste aspecto, a crença nas assombrações, que se tornam contos mediante os relatos, fornece uma visão privilegiada de como a discursividade é vivenciada e como o sentimento religioso é capaz de motivar as ações humanas a partir de seus símbolos tomados como sagrados. Consequentemente, eles "[...] funcionam para sintetizar o ethos de um povo - o tom, o caráter e a qualidade de sua vida, seu estilo e disposições morais e estéticas - e sua visão de mundo [...]" (GEERTZ, 1989, P. 67).

S.R.B. nos trouxe outro "causo", de grande dificuldade interpretativa em face da peculiaridade da narrativa e que coloca em perspectiva a noção de agência, mostrando-nos a relevância do local da morte dentro do sistema simbólico local ${ }^{8}$. Segundo ela, seu tio foi assassinado perto de sua casa e naquele espaço apareciam constantemente várias almas "Porque é como nesta cruz que foi matado o meu tio [...] eu não cheguei a conhecer [...] vinha essa procissão até na minha casa." E continuando "E via os vultos. Eram pessoas e você não via os rostos e tinha um pano branco coberto [...] só ouvia aquele gemido [...] vinham (andando) da cruz até ali na casa." (S.R.B., entrevista, 31/07/2012, Caldas). Esta narrativa fornece-nos elementos do imaginário popular para pensarmos a ligação entre a procissão das almas e o assassinato e que pode ser observado através dos gemidos, entendidos por Azzi (1978) como pedidos de ajuda e que são sanados apenas com rezas e o acendimento de velas.

A categoria assombração possivelmente pode conter variações dentro da perspectiva destes agentes, diferenciando-se em termos de sentido e descrição. Desta forma, o que é entendido como assombração adquire maior complexidade e que ao circular pelo município é incorporado por determinadas pessoas que podem transmitir estes significados. Verificamos, portanto, que a concepção dos agentes acerca das assombrações é bastante plu- 
ralizada. Nesse sentido, é importante mencionar que as pessoas evangélicas que conhecemos se referiram às assombrações apenas em um único sentido - "coisas do diabo" - o que mostra a presença de mais um elemento que se integra a este hibridismo, a figura do diabo, que também existe no universo católico popular caldense, mas é muito mais forte entre os evangélicos. Discurso que foi construído, em partes, a partir das influências de diversos programas religiosos de canais abertos de televisão que retratam esta presença ativa do diabo no cotidiano das pessoas através de possessões e encostos?.

Esta complexidade que envolve as assombrações é perceptível na narrativa de L.A.S. quando perguntado se conhecia algum "causo" sobre corpo seco, figura comum nos "causos" da comunidade. A estrutura do conto mostra a relação desta criatura viva com determinados fenômenos naturais.

Meus primos estudavam em Caldas, e moravam no bairro Botafogo, moram lá
ainda, uns moram, outros já foram embora, porque eles vinham para a escola à
noite, trabalhavam durante o dia e vinham à noite e daí o ônibus não conseguia
ter acesso lá no bairro. Daí eles desciam no [...], deixavam eles no [...] na beirada
do caminho lá, e tinham que descer a pé até a casa deles e tinha um comentário
que tinha um corpo-seco lá no mato. Daí um colega deles falou assim 'Duvido
que vocês pedem areia.'. Daí meu primo muito [...] louco começou a gritar 'Eu
quero areia, eu quero areia.'. Até aí tudo bem, de repente, o mato começou, es-
tava parado o tempo assim, começou a ventar devagar, foi aumentando. De re-
pente começou aumentando o vento, cada vez mais aumentando [...] de repente,
as árvores batiam até os galhos no chão. Foi indo e foi indo. Foram embora
correndo. Depois disso nunca mais pararam lá e desceram a pé. Foi preciso meu
tio buscar eles em um fusca velho que ele tinha lá [...] eles falaram que até hoje
não passam a pé lá (L.A.S., $25 / 07 / 2015,26$ anos, Caldas).

O ponto em que se ancora a existência desta assombração denominada "corpo-seco" com determinadas forças da natureza, amalgama outros elementos importantes dentro do sistema simbólico local. Em nossas incursões a campo tivemos contato com várias histórias distintas desta criatura singular e encontramos algumas interpretações que apresentam similaridades. Muitos agentes informaram-nos que o corpo-seco é uma pessoa que cometeu um pecado muito grave em sua vida e está recebendo uma punição, que é o impedimento de morrer. Dentro das possibilidades de pecado, a mais recorrente ao corpo-seco refere-se aos maltratos aos pais, sobretudo às mães ${ }^{10}$. Neste aspecto, podemos entender que as assombrações são símbolos (re)produtores de sentidos e 
que são relevantes para o agente que conta as narrativas (ORLANDI, 2015).

Estas narrativas permitem-nos pensar a proximidade entre a cultura popular e uma crença construída coletivamente e permeada por várias cosmovisões, cuja permeabilidade possibilitou a formação de práticas e representações diversas e originais (MELLO e SOUZA, 1986). Grande parte das narrativas que tivemos acesso seja por meio de entrevistas ou conversas não registradas, mostraram-nos a presença marcante de um catolicismo que foi se diversificando em meio a tantas dificuldades materiais que a Igreja Católica encontrou para controlar a região de Caldas, um território marcado pela mobilidade de pessoas e idéias até o início do século XIX.

Ao considerarmos a presença deste catolicismo em várias narrativas de assombrações, procuramos inseri-lo dentro de um aporte teórico denominado de catolicismo popular por Riolando Azzi (1978).

O catolicismo popular, em suas diversas manifestações históricas, esteve sempre bastante próximo dos cultos africanos e ameríndios, gerando não poucas vezes expressões religiosas que podem ser consideradas como verdadeiro sincretismo religioso (AZZI, 1978, p. 11).

Esta concepção de Azzi dialoga com nossa percepção acerca das inúmeras formas que as religiosidades foram se confeccionando em Caldas a partir das relações sociais cotidianas e que se desenvolveram afastadas do centro do poder religioso local. Da mesma maneira, o conceito de popular acaba adquirindo uma tonalidade emblemática dentro de nossa análise, sobretudo porque ele nos fornece um fundamento para pensar as tecituras construídas mutuamente, que foram possíveis pelo dinamismo das convergências culturais.

Nesse sentido, não podemos observar a cultura popular sob uma lógica escatológica, na qual o desenvolvimento dos meios de comunicação destinam crença nas assombrações e outras práticas religiosas ao desuso e a descrença. Sua vivência em Caldas se deve à sua capacidade de adaptação a estas novas formas de cultura que estão além da territorialidade local. A comunhão destes seres com o mundo material esteve presente na gestação de uma identidade coletiva que permanece em curso, perpassando, portanto por transformações e as assombrações se encontram neste processo exibindo-nos uma característica fundamental à permanência, a plasticidade e as variações (HANNERZ, 1997). 
laram para mim que tinha a [...] mula-sem-cabeça. Não é possível que tem isso aí? Daí [...] esses dias para trás eu estava em casa, acho que era uma quinta-feira, eu estava assistindo jogo [futebol]. Acabou e eu fiquei ouvindo uns comentários lá do jogo. Já era tarde, duas e meia da manhã e nisso, do nada, escutei um barulho de um, parece um cavalo passando na rua. Achei muito esquisito e saí para fora e não vi nada. Daí me veio o lance que falaram da mula-sem-cabeça. (L.A.S., 25/07/2015, 26 anos, Caldas)

Este trecho da entrevista de L.A.S. fornece-nos aspectos para pensar a cultura a partir de uma maleabilidade além de denunciar a idéia de uma essencialidade nas narrativas de assombração à medida que a mula-sem-cabeça, cuja representação comumente pode ser naturalizada a ambientes rurais e escuros, se renove e passe a habitar ambientes urbanos e iluminados no século XXI. É elucidativo, da mesma maneira, pensar como as representações sobre estas criaturas podem adquirir uma tonalidade de explicação da realidade em momentos nos quais os parâmetros racionais não parecem apreender o real de forma satisfatória.

Os contos que retratam as mulas-sem-cabeça são incomuns no município e foram raras as ocasiões que tivemos contato com este gênero das assombrações, ao contrário de almas penas e corpos-secos. Nesse sentido, emerge outro ponto emblemático sobre a vivência destes seres no cotidiano local, alguns relatos aparentemente possuem suas explicações de forma mais explícita do que outros e em algumas narrativas, o sentido parece residir na própria afirmação da existência da assombração, como observamos no trecho citado acima e algumas que retratam a existência de criaturas que moram nas matas e atacam as pessoas que passam por ali, conhecidas como bichos.

Nossas experiências com a população local permitiram que evidenciássemos a crença nas assombrações como uma das possibilidades de compreensão da realidade que permeiam o cotidiano de alguns moradores. Assim, o contato com elas pode acontecer em qualquer momento do dia. Na entrevista realizada com R.E.N., observamos um destes relatos que está atrelado à sua história de vida, rotina diária e nos traz outra amostra da presença do modo vida rural, ainda que nossa narradora contou que morou apenas na cidade. Esta colocação é capaz ainda de mostrar que a urbanização, observada como inevitável e natural, não pode ser pensada como um processo de desaparecimento do mundo rural como modo de vida (CARNEIRO, 2008).

Nós fomos buscar lenha. Aí eu estava [...] aí eu fiz meu feixe de lenha e a minha companheira estava amarrando o dela e eu escutei um barulho, só que eu achei 
que era ela. Aí eu fui acompanhando aquele "trupé" [passos] pensando que era ela. [...] E eu fui descendo mato abaixo. $\mathrm{Na}$ hora que eu olhei assim, juro por Deus, aí eu vi ela com a blusa verde [distante]. Aí eu falei "Margarida, olha o 'trupé', eu estava acompanhando o 'trupé”'. Depois eu não consegui colocar o feixe de lenha na cabeça, ela que colocou [...] $\mathrm{Na}$ hora que vi uma pessoa andando e fui seguindo e ela estava no lugar e eu fui descendo para baixo. (R.E.N., entrevista, 06/01/2017, 54 anos, Caldas)

As assombrações também são pensadas dentro de uma dicotomia que envolve as dimensões do sagrado e do profano para aqueles cuja crença esteja atrelada ao catolicismo. Partindo deste pressuposto, é importante salientar a existência de práticas mágicas que combatem determinadas aparições ou que atuam como mecanismos preventivos, como aquelas exercidas pelos benzedores a partir de suas rezas em rituais privados e que também são considerados como detentores do poder de cura, contra mau olhado e outras enfermidades.

Nesse mundo das representações caldenses, os relatos de agentes que ouviram ou viveram a experiência do contato com estes seres são fundamentais para a reprodução social da crença, ainda que ela possa ser apropriada de inúmeras maneiras pela população. No plano de fundo destas narrativas que são transmitidas oralmente, ao observamos as mensagens contidas em suas estruturas, encontramos a nítida presença do discurso católico.

Ao constatarmos estas mensagens e a forma como são apropriados pela população local, encontramos a presença deste discurso assentado na ideia de punição e pecado, como é possível observar na narrativa seguinte, na qual a alma de uma moradora passou a vagar na rodovia que dá acesso ao distrito de Pocinhos de Rio Verde porque ela era prostituta.

Ela chamava Ana do Zé Jonas. Ela era uma pessoa [...] como posso dizer [...] tinha uma vida um pouco irregular. Ela era meio macumbeira [...] Depois que ela morreu, todos os carros que desciam para Pocinhos, principalmente os táxis, ela descia de carona até a casa dela. Sentiam também o banco do carro afundar como se alguma pessoa estivesse lá. O carro podia pisar fundo no acelerador que ela iria junto até chegar na casa. Quando chegava lá, aquilo aliviava e a pessoa descia suando para Pocinhos (C.Z.L., entrevista, 03/01/2015, 72 anos, Caldas).

Este conto novamente traz à luz as aproximações entre as noções de pecado e punição dentro da tradição popular, mas acima de tudo, transmite aos seus ouvintes a ideia de que a ação de pecar pode acontecer a qualquer agente que se de- 
salinhe da perspectiva moral. A prostituição emerge, neste contexto, como um ato que é socialmente desaprovado e tão pouco perdoado por Deus e sua importância para a reprodução das formas de sociabilidade assenta-se na ideia de que Ana é um exemplo que não pode ser seguido. Na prática do contar, a comunicação e a fala não podem ser pensadas fora de uma materialidade simbólica (ORLANDI, 2015). Assim, todos os elementos que rodeiam este "causo" estão muito bem articulados e dialogam com alguns preceitos sociais e religiosos que são considerados fundamentais para uma parcela da população caldense. Entretanto, observando além desta perspectiva de normatização das formas de pensamento e comportamento, podemos encontrar em Ana a noção da agência, presente em suas ações, mediadas por seus interesses e que lhe renderam um estigma social que se estendeu para além de sua vida - se tornou uma narrativa de assombração conhecida na localidade.

Neste processo de construção e permanência de normas sociais convencionadas, os usos da memória, pertencentes a um discurso que é carregado por uma visão de mundo (ORLANDI, 2015), são essenciais para a manutenção da crença nas assombrações, transmitindo para as novas gerações estas formas de comportamento. A família possui papel relevante neste contexto, ao atuar como um núcleo de transmissão da fé (AZZI, 1978), agenciando a construção moral do indivíduo e da identidade coletiva. Considerando a interpenetração da religiosidade nos contos, a prática do contar se configura, em grande medida, como um ensinamento religioso, sobretudo ao entendermos que as suas experiências estão muito presentes nos ambientes privados da vida doméstica. Assim, o medo emerge como um mecanismo que contribui na difusão da crença e na solidificação de determinados valores católicos, como podemos observar na fala de M.B.F., professora aposentada, relembrando sobre sua infância.

Durante a infância [...], à noite, meu pai sentava na taipa do fogão. Nós, os filhos todos, sentávamos em volta. Alguns momentos ele ia nos ensinar rezar. Nos outros momentos, depois que ensinava, ele ia contar as histórias de assombração do tempo que ele era moço, que saía muito [...] e é lógico que nós tínhamos um medo terrível. (M.B.F., entrevista, 04/04/2012, 66 anos, Caldas)

A internalização destes valores vistos nos contos, nas rezas e em atos devocionais, em muitas ocasiões coletivas, podem prevenir a aparição das assombrações, uma vez que elas podem surgir para castigar uma pessoa que cometeu um pecado. Ainda que os agentes sociais locais atuam segundo seus interesses, não 
podemos negar a presença de uma ordenação cósmica dentro deste sistema simbólico e que contribui para determinar a interpretação da experiência (GEERTZ, 1989). Um de nossos narradores nos informou que certa vez na casa de sua avó, localizada nas proximidades do distrito de Santana de Caldas, uma assombração, em um dia de Quaresma, estava batendo na lata que servia para dar milho aos porcos e a cela começou a se movimentar sozinha mesmo estando pendurada na parede. Sua avó, não sabia explicar porque aquilo estava acontecendo, do ponto de vista religioso, porque ela se considerava muito católica e tudo aquilo que estava acontecendo, não lhe fazia sentido "Não estou fazendo nada para ninguém e quero que se tiver de fazer alguma coisa, que venha e faça aqui." (V.T.S., entrevista, 20/03/2012, 28 anos, Caldas). Sua reação foi bastante incomum ao enfrentar algo desconhecido, o que nos indica elementos para pensar na autonomia de sua ação em consequência de sua interpretação sobre estes acontecimentos.

Os contos possuem este caráter da religiosidade em um discurso fortemente alimentado pelo medo e ao pensarmos em seu processo de cristalização no cotidiano da população de Caldas e atrelarmos a este pressuposto a falta de padres e a extensão territorial da região, podemos entender que a crença nas assombrações e a confecção das narrativas na oralidade serviram como forma de transmissão dos princípios católicos, sobretudo porque o acesso aos textos bíblicos e a questão da alfabetização entre as pessoas são elementos que não podem ser desconsiderados. Assim, a oralidade, em virtude desta carência estrutural que o catolicismo perpassou na América Portuguesa, contribuiu de forma significativa para a sua manutenção, mesmo que sua confecção cotidiana carrega profundas marcas de interação com outras religiosidades.

A constituição de uma identidade local, portanto, possui alguns elementos religiosos que foram assentados na memória coletiva, confirmando-nos que a incorporação da oralidade no cotidiano foi outra interface das práticas de improvisação. A presença viva destes seres no cotidiano, para uma parcela da população, pode ser interpretada sob a ótica da proximidade que as assombrações possuem com a população de Caldas, sobretudo porque muitas almas penadas ou lobisomens foram habitantes de bairros específicos do município. Deste ponto emerge as peculiaridades locais através de práticas e imaginários, cuja natureza não foi fundamentada em Caldas, mas que se confeccionaram coletivamente em um processo 
que envolve a tradução de aspectos culturais e a produção ainda de outros originais.

A memória permite que estes "causos" sejam monumentos ao possibilitarem a recordação do vivido (LE GOFF, 2003) e se constituam como uma tradição que foi tecida temporalmente ao longo dos séculos e que chega com vida no século mesmo que o advento da globalização trazendo consigo a mobilidade das ideias muita intensa, colocando em campo outras possibilidades de práticas religiosas e culturais distintas daquelas produzidas na localidade (APPADURAI, 2008; HALL, 2002), produzindo redes transnacionais que atuam na ressignificação da cultura local em um processo que envolve a tradução cultural e a perspectiva de agência.

A evocação das lembranças transmite os fundamentos religiosos dos contos, permitindo a manutenção de laços identitários (BOSI, 2003), mesmo que estes sempre estejam passando por transformações bem como a própria estrutura das narrativas e da crença nas assombrações, sobretudo quando consideramos os avanços tecnológicos da globalização que facilitaram o trânsito de ideias, discursos e formas culturais distintas.

\section{Globalização e convergências culturais: a mobilidade das ideias entre os jov- ens caldenses e as transformações na cultura popular local}

A crença nas assombrações caldenses aloca-se sobre uma característica peculiar, sua facilidade em se adaptar a novos contextos ao longo do tempo. A presença das assombrações é visível na cotidianidade e entorno de si flutuam outras práticas e imaginários que envolvem a religiosidade, e que também estão inseridas neste momento da história. O advento da globalização no município colocou em movimento as crenças religiosas e a cultura popular local ao inserir novas ideias, trazendo novas perspectivas de pensamento, o que coloca o campo do discurso em conflito, uma vez que os meios de comunicação possibilitaram que os agentes locais tivessem contato com outros imaginários, muitos distantes em termos de espacialidade e que podem contribuir nas transformações da cultura local (APPADURAI, 2008).

Estas disposições culturais no campo social permitiram o contato cada vez mais profundo com outras formas de cultura, o que entendemos diversificar a possibilidade de agência e da tradução cultural, que se projeta no dinamis- 
mo do imaginário local e na forma como ele se apresenta. O contato com tais fluxos implica em transformações da cultura a partir das experiências vivenciadas pelos agentes e que ao colocarem a cultura em ação, participam de seu processo de ressignificação, condição necessária à sua vivência na contemporaneidade (HANNERZ, 1997). Neste contexto, observamos jovens andando de skate no centro do município ainda que as condições geográficas e físicas não favorecem esta prática à medida que a cidade possui bastante morros e em várias ruas não existe asfalto, apenas o calçamento feito por paralelepípedos.

Os fluxos culturais globais, por outro lado, não produzem impactos destrutivos na localidade, substituindo e proporcionando o desaparecimento de suas práticas culturais. A relação entre estas formas culturais globais e a cultura local ao colocarmos em perspectiva a noção de agência e considerando que ela já carrega intrinsecamente elementos da identidade local, a autonomia e os interesses do indivíduo, vislumbramos a globalização como uma possibilidade da diversificação cultural.

À medida que a cultura se move por entre correntes mais específicas, como o fluxo migratório, o fluxo de mercadorias e o fluxo de mídia, ou combinações entre estes, introduz toda uma gama de modalidades perceptivas e comunicativas (HANNERZ, 1997, p. 18)

Neste contexto entendemos que a interação entre a cultura local e a globalização não pressupõe uma possibilidade de homogeneização de práticas e imaginários, uma vez que existe um processo de tradução e de escolha dos agentes e sua forma de pensar está inscrita implicitamente em momentos de permeabilidade cultural. Paralelamente, tal colocação postula uma rejeição a qualquer visão que observa as interações culturais sob dimensões que carregam olhares cerrados sob os autos de uma heteronomia, neutralizando a noção da agência e destinando - de forma profética e fatalista - a extinção da cultura local.

Hall (2002) fornece-nos outro parâmetro para a compreensão das relações culturais ao afirmar que a globalização diversifica as culturas locais. Dentro desta possibilidade teórico-analítica o pensamento de Janice Theodoro (1992) corrobora em nossa perspectiva ao propor a ideia da vivência das culturas, mesmo em momentos históricos em que se explicitaram a dominação política, social e intelectual e nos quais emer- 
gem experiências de resistência, hibridismo e convergências culturais.

Assim, teorias que traçam discussões conceituais sobre a americanização negligenciam tanto a questão da alteridade quanto das diferenças culturais que se renovam mesmo em contextos de intensa interação social (MONTERO, 1997). Ao reificar as relações culturais dentro do campo maniqueísta, não conseguiremos avançar a reflexão para além de um lascasianismo cultural, no qual culturas locais são vistas unicamente como vítimas de um processo global e ininterrupto de assimilação e homogeneização, necessitando de salvação e preservação.

Em vez de um todo integrado e internamente homogêneo, como o poder de incorporar uma coletividade de pessoas num sistema de relacionamentos relativamente estável, a cultura passa a ser compreendida como um sistema de significados em conexão permanente com outros sistemas. (TRAJANO FILHO, 2010, p. 13)

As vivências cotidianas da população local com estes elementos transnacionais, mediadas pelo consumo de mercadorias, imagens e formas de pensamento, ao longo dos últimos anos, demarcam uma relativa fluidez no campo simbólico das fronteiras culturais. A mobilidade dos discursos que estão inseridos nestes elementos possibilitam transformações dentro da identidade coletiva caldense, dotando-a de dinamismo e variações internas. As mídias televisivas e a internet inseriram novos elementos na formação do hibridismo cultural em Caldas, como o aparecimento, há alguns anos, de uma academia de artes marciais mistas e um grupo de dança hip hop, e que representam a construção de novos imaginários (APPADURAI, 1996).

Este processo dinâmico da mobilidade das ideias não pode ser pensado exclusivamente como pertencente à estas ultimas décadas à medida que não podemos ignorar a presença do rádio e da televisão no século XX enquanto mecanismos que possibilitaram a circularidade das ideias. Esta consideração foi muito visível quando percebemos que grande parte da população masculina que frequenta determinados bares, após o dia de trabalho, para assistir partidas de futebol torce por diversos times de localidades diferentes no Brasil. Neste caso, o futebol por intermédio dos meios eletrônicos contribuiu na tecitura desta identidade coletiva plural, que se agregou à vida pública e privada desde a disseminação do rádio no município. 
Vale ainda ressaltar que o futebol internacional passou fazer parte do cotidiano desta parcela da população que se identifica com o esporte, independente da faixa etária. Não raramente observamos pessoas usando camisetas de clubes europeus, não apenas para praticar o futebol na quadra municipal, localizada no Palácio da Uva. Seu uso cotidiano é bem frequente e os bares passaram a transmitir as partidas européias ao vivo, normalmente pela tarde, o que reúne uma quantidade pequena de pessoas. Isto se deve, em grande medida, ao fato deste período ser o horário comum de trabalho na cidade. Assim, estes indivíduos que frequentam os bares nesta parte do dia estão desempregados ou em dia de folga, além de jovens que cursam graduação na cidade vizinha de Poços de Caldas ${ }^{11}$.

Os jovens caldenses se encaixam dentro desta perspectiva de incorporação de outras possibilidades culturais, afirmação que pode ser vista como naturalidade por esta nova geração, sobretudo porque a temporalidade destes jovens é marcada dentro de um contexto de visível transculturalida$\mathrm{de}^{12}$. Entretanto, não nos cabe colocá-los em um quadro de distanciamento acerca do sistema simbólico local, como se suas formas de pensamento e ações fossem estruturadas unicamente por discursos globais. Estes fazem parte das representações coletivas dos jovens e modificam sua relação com as tradições da comunidade, o que não implica em afirmar seu abandono e tão pouco sua substituição. Dessa forma, a crença nas assombrações e a prática do contar permanecem no cotidiano, mas podem adquirir novos sentidos e tonalidades, como o entretenimento e o que identificamos, na perspectiva do campo do discurso, é um confronto entre ideias distintas.

A interface deste conflito entre formas discursivas divergentes compreende de forma mais profunda uma luta pela visão de mundo, em que o poder católico presente na confecção social da população vem disputando espaço com outras perspectivas simbólicas, que não são exclusivamente religiosas. Estas são capazes de confeccionar identidades coletivas dispersas globalmente, como o cinema e os desenhos animados, que transmitem visões de mundo de forma sutil, influenciando na construção de imaginários que dinamizam e pluralizam o cotidiano de Caldas, porém sem indicar um afastamento da crença nas assombrações. Esta interação é visível, como observamos em um trecho da entrevista com J.P.V.G., um jovem morador do distrito rural de São Pedro de Caldas. 
Tem outra história, fiquei sabendo ontem, foi minha mãe que contou. Está acontecendo ainda. Teve um cara lá em São Pedro, ele se chamava “A.”. Aí ele já estava mais velho e ele falou que tinha gente atrás dele sabe [...] ele tomou veneno e suicidou lá [...] Aí quando vê, a velha [esposa] começou a bater na porta [do quarto] assim e gritar sabe O "A." está aqui, o "A." está aqui. Aí a mulher [filha do casal] foi e destrancou a porta. [Ela perguntou] O que está acontecendo? [...] Aí a velha falou que ele começou a cochichar no ouvido dela e na hora que ela levantou, viu ele sentado na cama sabe e foi essa semana (J.P.V.G, entrevista, 04/08/2016, Caldas).

A presença de uma cultura popular transnacional na vida de nosso narrador pode ser observada em suas práticas sociais ao nos afirmar sua preferência pelo rap brasileiro e estadunidense e que ainda se soma à sua religiosidade católica e ao medo das assombrações. Estas formas culturais amalgamadas mostram-nos alguns aspectos da interação entre a cultura local e a global e reforça-nos a presença do hibridismo edificado em aspectos globais e permeado por escolhas individuais.

Neste sentido, uma estudante disse que usa a internet como forma de entretenimento, gosta de filmes produzidos em Hollywood e apreciava rock. Não podemos ignorar a premissa colocada por Hall (2002), na qual a presença destes elementos produzem identidades fragmentadas, entretanto não podemos compreender estes agentes apenas sob este ponto único de ancoragem. Seu conhecimento acerca das narrativas de assombração elucidamnos sobre a vivência desta crença no cotidiano e a permanência da prática de contar enquanto discurso religioso que orienta as pessoas sobre o pecado.

Tinha um rapaz que maltratava a mãe dele, e um dia, quando chegou do trabalho, ela não tinha feito almoço ainda porque estava arrumando a casa. Aí tinha uma cela [de cavalo] [...] Ele pegou, empurrou ela e colocou-a nela. Começou a bater nela com aquele negócio. Depois ele sofreu um acidente e contam que ele voltou, mas que ele tem corpo de animal, mas a cabeça é dele mesmo. (J.A.T.A., entrevista, 15/09/2015, Caldas).

Mesmo que o processo histórico possa transformar os significados culturais e as categorias locais ao absorver outros discursos, entendemos que as assombrações e seus relatos passam por determinadas modificações de sentido o que lhes garante vivência na contemporaneidade. Neste aspecto é interessante refletir sobre sua permanência em contraponto às perspectivas que racionais prometem explicar a realidade imediata, sobretudo se considerarmos seus avanços nestas últimas décadas. A racionalidade, nesse sentido, se comporta 
também como um discurso que está posicionado no campo das tentativas de dominação e acaba entrando em conflito com a visão de mundo religiosa caldense. Entretanto, esta aparente relação tensa entre discursos de epistemologias distintas pode não ser percebida pragmaticamente nas relações sociais locais, uma vez que diversas formas culturais globais tenderam a naturalizar-se no cotidiano, mas não deixando de dialogar com o sistema simbólico local.

Meus pais que viram isso. Me parece que eles moravam em uma casa antiga, bem longe da cidade, na roça, mas não sei direito onde. E lá aparecia um gato preto toda noite e eles falaram que ele explodiu e no outro dia voltava, como se nada tivesse acontecido. Coisa estranha (J.N.S.J., entrevista, 15/09/2015, Caldas).

A estrutura deste "causo" não possui uma grande complexidade tal como observamos em outras narrativas, sobretudo quando olhamos para as gerações mais antigas. Esta observação ganha tonalidades mais fortes ao identificarmos que este jovem carrega um discurso mais cético em relação à existência das assombrações "Seilá, depende da história". Seu aparente distanciamento da crença desdobra-sena forma de contare na quantidade de histórias que ele possui em sua memória, o que nos permite pensar nas peculiaridades contidas em cada geração.

Segundo Sirinelli (2002) as características próprias das gerações gravitam em torno de fatos relevantes para as comunidades históricas, cujos elementos determinantes em sua constituição são variáveis em relação a outras comunidades. Nesse sentido, os jovens caldenses, enquanto uma nova geração, se tornam agentes importantes deste processo em que a globalização emergiu como acontecimento relevante em sua formação social, nos levando à reflexão de que as gerações possuem permanências e mudanças (SIRINELLI, 2002), contendo portanto, suas próprias peculiaridades, experiências e vivências que não sincronizam-se, em muitas ocasiões, com as temporalidades de gerações anteriores, possibilitando conflitos na dimensão das visões de mundo.

\section{Reflexões finais}

A globalização e seus aparatos de comunicação permitiram que as formas de pensar e agir adquirissem uma mobilidade que possibilitou convergências culturais dentro do município de Caldas, colocando em movimento seu sistema simbólico, o qual historicamente carrega as tonalidades do dina- 
mismo, do hibridismo e do trânsito, possibilitando-nos pensar a identidade coletiva sob o prisma da pluralidade. No campo do discurso, estas mensagens, presentes no consumo de imagens e produtos, antes de serem apropriadas pela população perpassam por um processo de tradução cultural, colocando em diálogo várias concepções de mundo, o que possibilita a diversificação da cultura local e da identidade pessoal. Considerando que os discursos se encontram em constante movimento e não podem ser entendidos como acabados (ORLANDI, 2015), entendemos que esta condição, presente na história, possibilita a confecção de imaginários e práticas híbridos, cujos sentidos estão assentados em múltiplas formas convergentes de ideias.

Os usos de determinadas práticas que são de caráter transnacional ao estabelecerem convergências com a cultura caldense, em especial com a crença nas assombrações, modificaram-na, porém esta é uma condição necessária à sua vivência no cotidiano e uma de suas principais características - sua fluidez e mobilidade. Assim, entendemos que estas relações entre saberes distintos, como discutiu Liliana Porto (2007), não pode ser analisada por uma ótica do abandono das crenças locais em contraposição a eficácia do discurso sobre conhecimento científico enquanto único modelo de conhecimento do mundo. Partindo da premissa do dinamismo interno da cultura popular, tal como Bhabha (1998) sugeriu, não podemos considerar a existência de uma identidade original, ainda que a tradição seja uma forma de pertencimento, o que equivaleria ignorar não apenas o processo de formação cultural de Caldas, mas do Brasil.

Estabelecer demarcações referentes à natureza e ao fim que determinadas práticas consiste em abandonar a visão da cultura fundamentada no dinamismo e na plasticidade, colocando-lhe sobretudo limites temporais e dialógicos. O panorama deste contexto leva-nos a entender que a crença nas assombrações tem passado por transformações históricas, nas quais os agentes exercem papéis fundamentais, o que coloca a cultura em movimento, como assinalou Sahlins (1990). Constatamos que as modificações na relação dos jovens com as narrativas de assombração podem ser vistas na perfomance contar no sentido de que seus contos são relativamente menos detalhados e no pequeno número de histórias que eles conheciam, o que nos permitiu refletir que o medo e a religiosidade, elementos edificantes da crença, passaram 
por alterações diante da apropriação de outras formas culturais e discursos.

Estas transformações, em muitas ocasiões, são vistas a partir de uma escatologia cultural e representam de forma profunda o embate entre discursos e as visões de mundo distintas debruçadas sobre as perspectivas maniqueístas da dominação. Não podemos conceber, portanto, a presença dos contos de assombração no cotidiano local, como algo fadado ao desaparecimento no mesmo processo em que as culturas humanas vão se tornando homogêneas.

Segundo Hall (2003), o local e o global não podem ser analisados de forma cindida, condição essencial para a análise das relações culturais no mundo contemporâneo. A partir dessa interação, os contos de assombração bem como outros estratos da cultura popular caldense que estão atrelados a uma religiosidade vivem no cotidiano e fornecem elementos que residem no sentimento de pertencimento, ainda que as convergências com outras formas culturais criem laços plurais de identificação que se manifestam no universo mental dos jovens.

No plano de fundo dessas relações dialógicas, a intensa mobilidade das ideias na contemporaneidade ascendeu novas opções de escolha em termos culturais, que era diferente em outras temporalidades históricas. Portanto, estas interações, ao focarmos nosso olhar sobre a dimensão teórica da cultura, implicam, sem dúvida, em tensões e conflitos, uma vez que determinados elementos carregam mensagens epistemologicamente distintas, mas que convivem por se tratarem de escolhas dos agentes sociais. Assim, mediante estes fluxos culturais que disputam o campo com as ideias produzidas historicamente em Caldas, notamos que a relação dos jovens com as narrativas de assombração se apresenta de forma diferente, não inexistente ou alegórica, contudo, menos intensa e próxima do que nas gerações anteriores, o que pode ser algo referente à idade e à experiência em relação aos mais velhos. Esta consideração indica-nos que a identidade das novas gerações possui características tradicionais, de recriação, efemeridade e pluralidade, todas em articulação e consonância e que as variadas formas de apropriação dos contos e das crenças populares evidenciam acima de tudo a presença da agência na localidade. 


\section{Notas}

1. Gilberto Freyre (2006) fornece explicações importantes sobre nome bugre dado a determinadas etnias nativas no período da colonização. Segundo o autor, a palavra exprime a ideia católica de pecado imundo e se referia a uma etnia específica de São Paulo. Esta consideração de Freyre pode elucidar-nos acerca da presença paulista, em termos de ocupação, na formação das primeiras vilas no sul de Minas Gerais.

2. Cabe considerar, neste ponto, que a concepção que percebemos da população sobre assombração a partir da experiência de campo é bastante complexa à medida que abarca estes espíritos, almas penadas de antigos habitantes, lobisomens e criaturas noturnas que habitam as matas, que não encontramos descrições, sendo nomeadas como "bichos".

3. Esta região envolve hoje, além de Caldas, os municípios de Poços de Caldas, Andradas, Santa Rita de Caldas e Ibitíura de Minas, todos pertencentes à comarca de Caldas até meados do século XIX, o que nos proporciona uma amostra de sua extensão territorial.

4. Nossa concepção de hibridismo cultural perpassa pela discussão fundamentada por Burke (2010). Assim, observamos o conceito sob o prisma de uma construção dinâmica, conjunta e ininterrupta formada por múltiplos encontros culturais que possibilitam a diversificação, permeabilização e emergência de representações e expressões cotidianas.

5. É a forma como os agentes locais normalmente se referem às narrativas de assombração.

6. Encontramos na obra Assombrações do Recife Velho, de Gilberto Freyre (1987), algumas narrativas que possuem traços semelhantes com os contos caldenses.

7. Optamos por ocultar o nome da mulher morta por uma questão de respeito à família bem como dos envolvidos no conto, uma vez que esta narrativa é bastante recente na cidade. Assim, decidimos chamá-la de Lurdes.

8. Adotamos o conceito de agência a partir de Ortner (2006) que aprofunda a perspectiva de Sahlins entre estrutura e ação, observando-o sob a ótica da intencionalidade na ação, movida por interesses e desejos, mas que opera dentro dos limites da cultura.

9. Nos últimos anos cresceu o número de igrejas evangélicas na cidade, algumas delas filiadas a estas vertentes evangélicas que tem programas específicos na televisão.

10. Verificamos que as assombrações, na maioria das narrativas que tivemos acesso, sejam elas gravadas, escritas ou ouvidas, se relacionam com uma noção de pecado que está ligada à alguma forma punitiva. Entretanto, nesta relativa relação pecado e punição divina, existem as assombrações que pagam por eles em vida, como os corpos-secos e os lobisomens. Dentro desta perspectiva identificamos a existência de outra variação na concepção local, em face da possibilidade da punição concretizar-se após a morte, como é o caso das almas penadas de antigos moradores do município.

11. Em Caldas não existe nenhuma universidade ou centro de educação superior.

12. Nossa delimitação sobre a noção de jovem seguiu os parâmetros estabelecidos pelo IBGE que compreende as idades entre quinze e vinte e quatro anos. Consulta via internet realizada no dia 05/04/2016 (http://www.ibge.gov.br/home/). 


\section{Referências}

ALBERTI, Verena. Manual de história oral. Rio de Janeiro. FGV Editora, 2005. APPADURAI, Arjun. Dimensões culturais da globalização. Lisboa: Teorema, 1996.

- A vida social das coisas: as mercadorias sob uma perspectiva cultural. Niteroi: UFF, 2008.

AZZI, Riolando. Catolicismo popular no Brasil: aspectos da história. Petrópolis: Vozes, 1978.

BHABHA, Homi K. O local da cultura. Belo Horizonte: Editora UFMG, 2008. BOSI, Ecléa. O tempo vivo da memória. São Paulo: Editora Ateliê, 2003.

BRANDÃO, Carlos Rodrigues. Tempos e espaços nos mundos rurais brasileiros. Ruris: Revista do Centro de Estudos Rurais, Universidade Estadual de Campinas, v.1, n.1, p 37-64, 2007.

BURKE, Peter. Cultura popular na Idade Moderna. São Paulo: Companhia das Letras, 1989.

. Hibridismo cultural. São Leopoldo: Editora Universidade do Vale do Rio dos Sinos, 2010.

CÂNDIDO, Antonio. Parceiros do Rio Bonito. São Paulo: Saraiva, 2010.

CARNEIRO, Maria José. Rural como categoria de pensamento. Ruris: Revista do Centro de Estudos Rurais, Universidade Estadual de Campinas, v.2, n.1, p 9-38, 2008.

DELUMEAU, Jean. História do medo no ocidente 1300-1800: uma cidade sitiada. São Paulo: Companhia das Letras, 2009.

DUBY, Georges. Ano 1000, ano 2000: na pista de nossos medos. São Paulo: Editora

UNESP/Imprensa Oficial do Estado de São Paulo, 2003.

ELIADE, Mircea. O sagrado e o profano. São Paulo: Martins Fontes, 1992.

FREYRE, Gilberto. Assombrações do Recife Velho. Rio de Janeiro: Record, 1987. 
. Casa-grande e senzala: formação da família brasileira sob o regime da economia patriarcal. São Paulo: Global, 2006, 51ª edição.

GEERTZ, Clifford: A interpretação das culturas. Rio de Janeiro: Ed. Guanabara, 1989.

- O saber local. Novos ensaios em antropologia interpretativa. Petrópolis: Vozes, 1997.

HALL, Stuart. A identidade cultural na pós-modernidade. Rio de Janeiro: DP\&A, 2002.

. Da diáspora: Identidade e mediações culturais. Belo Horizonte: Editora UFMG, 2003.

HANNERZ, Ulf. Fluxos, Fronteiras, Híbridos: palavras-chave da antropologia transnacional. Mana, Rio de janeiro, 3(1): 1997.

LE GOFF, Jacques. História e Memória. Tradução Bernardo Leitão. Campinas: Editora da Unicamp, 2003.

MALINOWSKI, Bronislaw. Argonantas do Pacifico ocidental: um relato do empreendimento e da aventura dos nativos nos arquipélagos da Nova Guiné Melanésia. 2. ed. São Paulo: Abril Cultural, 1978.

MELLO e SOUZA, Laura de. O Diabo e a terra de Santa Cruz. São Paulo: Companhia das Letras. 1986.

. Formas provisórias de existência. In: NOVAIS, Fernando (Coord.). História da vida privada no Brasil. Cotidiano e vida na América Portuguesa. Vol. 1. São Paulo: Companhia das Letras, 1997.

MONTERO, Paula. Globalização, identidade e diferença. Novos Estudos Cebrap, n. 49, p. 47-64, 1997.

MOTT, Luiz. Cotidiano e vivência religiosa: entre a capela e o calundu. In: NOVAIS, Fernando (Coord.). História da vida privada no Brasil. Cotidiano e vida na América Portuguesa. Vol. 1. São Paulo: Companhia das Letras, 1997.

MOURA, Margarida Maria. Camponeses. 2. ed. São Paulo: Ática, 1988.

NOVAIS, Fernando. Condições de privacidade na colônia. In: NOVAIS, Fer- 
nando (Coord.). História da vida privada no Brasil. Cotidiano e vida na América Portuguesa. Vol. 1. São Paulo: Companhia das Letras, 1997.

ORLANDI, Eni Puccinelli. Discurso, imaginário social e conhecimento. Revista Em Aberto, Brasília, n. 61, 1994.

- Análise de discurso: princípios e procedimentos. Campinas: Pontes, 2015, $12^{\mathrm{a}}$ edição.

ORTNER, Sherry. Poder e Projeto: Reflexões sobre Agência. In: GROSSI, M.; ECKERT, C; FRY, P. Conferências e Diálogos: Saberes e Práticas Antropológicas. Blumenau: Editora Nova Letra, 2006, pp. 45-80.

PIMENTA, Reynaldo. O povoamento do planalto da Pedra Branca - Caldas e região São Paulo: Rumograf, 1998. Obra póstuma.

PORTO, Liliana. A ameaça do outro: magia e religiosidade no Vale do Jequitinhonha (MG). São Paulo: Attar, 2007.

SAHLINS, Marshall. Ilhas de História. Rio de Janeiro: Jorge Zahar, 1990.

SIRINELLI, Jean-François. A geração. In: FERREIRA, Marieta de Moraes. AMADO, Janaína. Usos e abusos da História Oral. Rio de Janeiro: Editora da FGV, 2002. 5 edição.

SWEET, James H. Recriar a Africa. Cultura, parentesco e religião no mundo afro-português (1441-1770). Lisboa: Edições, 2007.

THEODORO, Janice. América barroca. São Paulo: Edusp, 1992. 


\title{
Tales of haunting and popular Catholicism: aspects of religious life in a Minas Gerais community
}

\begin{abstract}
This article discusses the foundations and dimensions of a traditional practice in the town of Caldas, Minas Gerais, telling narratives of ghosts, not only as a stratum of local popular culture, but putting in perspective a popular religiosity hybrid character. Once immersed in the oral tradition and collective memory, the mobility of ideas and the imaginary contained in tales enabled this belief system is present in the local daily life and dialogue with other cultural practices and ways of thinking that have become accessible to the population through the apparatuses of electronic communication. In this sense, the methodology of oral history and the collecting ethnographic data allowed us to enter this mental universe and investigate the relationship of the population with hauntings.
\end{abstract}

Keywords: Tradition; Religious Practice; Anthropology of Religion; Imaginary; Globalization

Recebido em 01 de maio de 2017. Aceito em 11 de julho de 2017. 